Научная статья

УДК $111.1+114$

DOI: 10.18101/1994-0866-2021-4-26-31

\title{
ТЕОРИЯ ПРИЧИННО-СЛЕДСТВЕННЫХ СВЯЗЕЙ В ФИЛОСОФИИ КИТАЙСКОГО БУДДИЗМА
}

\section{(C) Дашеева Вера Витальевна}

кандидат филологических наук, доцент, Бурятский государственный университет имени Доржи Банзарова Россия, 670000, г. Улан-Удэ, ул. Смолина, 24a denisova.v@mail.ru

\author{
(C) Хандархаева Виктория Викторовна \\ старший преподаватель, \\ Бурятский государственный университет имени Доржи Банзарова \\ Россия, 670000, г. Улан-Удэ, ул. Смолина, 24а \\ khandarkhaeva@yandex.ru
}

\begin{abstract}
Аннотация. Причинно-следственные связи являются важным аспектом в понимании философии китайского буддизма. В статье обсуждается идея о взаимодействии всех явлений и предметов природы бытия, которые не обладают реальной сущностью, а являются следствием их пустотности, не имеющей отрицательного качества. Философия китайского буддизма указывает на гармоничность существования мира со всеми объектами, акцентируя на единство всего сущего с природой бытия. В данной статье рассматриваются классификации мировоззренческих аспектов причинноследственных связей, которые способствуют преодолению ложной картины мира так называемого «омраченного сознания», опровержению иллюзии субъектнообъектных отношений, достижению истинной природы бытия и гармонии всех причинно-следственных отношений. Возникновение школы хуаянь привело к формированию форм и методов в теории китайского буддизма. Автором данной теории является китайский философ Фа Цзану, который полагал, что возникновение всех вещей и явлений в природе бытия обусловлено причинно-следственными связами.

Ключевые слова: буддизм, философия Китая, китайский буддизма, причинноследственные связи, школа хуаянь, Фа Цзан, дхармадату, причинность, все сущее.
\end{abstract}

\section{Для цитирования}

Дашеева В. В., Хандархаева В. В. Теория причинно-следственных связей в философии китайского буддизма // Вестник Бурятского государственного университета. Философия. 2021. Вып. 4. С. 26-31.

В Китае буддизм имеет более двухтысячелетнюю историю распространения в период эпохи Хань. Известно, что во второй половине XIX в. исследовательская буддийская деятельность отличалась обособленным и раздробленным характером, в связи с чем не выдерживала противостояния с палийскими исследованиями и санскритскими канонами. Процесс взаимодействия буддизма с традиционной письменностью Китая оказал сильное влияние на формирование и дальнейшее развитие его направлений и школ. Переводы священных сутр стали первоначальным этапом ознакомления китайского государства с буддийским учением, которое осуществлялось через письменные тексты. Следующим важным этапом 
B. В. Дамеева, В. В. Хандархаева. Теория причинно-следственных связей в философии китайского буддизма

оказался процесс создания собственных трудов, затрагивающих тему буддизма. В Китае в этот период буддийские труды имели следующую направленность: исторические и биографические очерки, разнообразные изложения религиознофилософского содержания, сочинения, в которых описывалась хронологическая последовательность становления буддизма. По исследованиям А. С. Мартынова и Е. Б. Поршнева, иноземному учению пришлось столкнуться с устоявшейся политической, социальной и культурной традицией в Китае, имеющей глубокие корни, согласно которой государственная власть понималась как непосредственное продолжение благой созидательной работы Неба - высшей сакральной ценности на всем Дальнем Востоке [5].

Как считал Фа Цзан, теория причинно-следственных связей опровергает реальное существование объективного мира. Данная теория включает в себя сложный целостный комплекс, который состоит из звеньев цепи причинной зависимости каждого явления и предмета в природе бытия (пратитья-самутпада, «вторая благородная истина»). Перечислим самые важные тексты и комментарии мыслителя Фа Цзана: «Хуаянь фа путисинь чжан» («Очерки о способах пробуждения сознания бодхи в учении хуаянь»), «Хуаянь уцзяо чжан» («Очерки пяти учений хуаянь»), «Хуаянь цзин» («Гирляндовая сутра»), «Хуаянь ихай баймэнь» («Сто врат к неисчерпаемым глубинам учения хуаянь»), «Цисиньлунь ицзи» («Комментарии пробуждения веры в Махаяне»). В данном исследовательском поиске вызывает несомненный интерес идея единства истинности существования всех вещей и явлений, абсолютного и иллюзорного.

Важно отметить, что период первоначального проникновения буддизма в Китай совпал с экономическим и политическим кризисом правления ханьской империи. Согласно летописям 184 г. н. э., по всему Китаю вспыхнули волнения «желтых повязок» на целых 20 лет. Конфуцианство, как официальное учение ханьского правления, переживало кризис. В таких условиях буддизм среди народных масс стал обретать популярность, так как обещал избавить всех от страданий сансары. Буддизм, привлекая народные массы, заинтересовал и образованные слои общества, при этом сохранив во многом мистический образ. Для того чтобы очистить учение буддизма от множества мифов, осуществлялись попытки осознать и понять иноземное знание в обществе. В первую очередь началась переводческая деятельность буддийской литературы в том виде, который он проник из Индии в Китай.

Необходимо подчеркнуть, что буддизм стал распространяться в северных и южных частях Китая среди народных масс, так как был способен удовлетворить многие потребности. Как пишет Н. И. Конрад, «правящий класс находил в буддийской церкви могущественное орудие укрепления своей власти; образованные слои китайского общества были захвачены широтой буддийской философии; народные массы буддизм привлекал и своими красочными ритуалами, и обещаниями земных и небесных благ» [4].

Во время развития китайского буддизма возникали различные школы, как собственно китайские, так и синтез китайских и индийских традиций в период династии Тан. Причинами расцвета этих школ являлись поддержка и помощь со стороны правительства Китая, которое было заинтересовано в укреплении централизации власти и объединении Китая. Согласно принципам этих школ, в осо- 
бенности школы хуаянь, природа Будды находится во всем сущем. Следуя этим правилам, буддийский мир описывался адептами школ хуаянь через строгую иерархию буддийский понятий, в которой все сущее рассматривалось равнозначно единому - природе Будды.

Исследование философского учения школы хуаянь следует начинать с теории причинности как необходимого средства постижения метафизических основ всех буддийских школ Китая. Теория причинности занимает центральное место в учении, она использовалась как важнейший инструмент анализа и доказательства теоретических идей школы хуаянь.

Благодаря поддержке императрицы У Цзэтянь началась переводческая деятельность сутры «Хуаянь цзин». Известно, что это был второй перевод сутры под руководством Шикшананды. Первый перевод был неполным. Позднее переводческой деятельностью занимался основатель и патриарх школы хуаянь Фа Цзан (643-714) [3]. Главной идеей этой школы является постулат всеобщей взаимообусловленности и взаимопроникновения всех вещей в природе бытия. Согласно учению Фа Цзана, окружающий нас мир есть результат взаимодействия множества причинно-следственных явлений, в котором все представляется причиной и следствием всего сущего. Понятие слова «дхармадату» (фаизе) обозначает «совокупность всех событий, пространственно-временной комплекс, постоянно порождаемый - и каждый раз всего лишь на миг, в результате сложного взаимодействия всех элементов бытия» [1].

Фа Цзан отмечает, что существует четыре аспекта качественной характеристики термина четверичности «дхармадату»:

1) существования самих явлений;

2) обоснования всех явлений, в особенности понятия пустотности как истинной природы сущности вещей.

3) взаимодействия и взаимопроникновения вещей и явлений.

4) взаимосвязи всех явлений.

Согласно первому аспекту существования самих явлений, в учении описывается обыденное представление о мире, в котором существует совокупность различных явлений, не похожих друг на друга. Обоснованием всех явлений, понятия об отсутствии незаменимого, истинного существования вещей, самосущего бытия феноменов, основы всех вещей и явлений является пустота, утверждающая, что личность и феномены пусты от самобытия. Следовательно, в основе всего бытия лежит пустота, которая не противоречит реальности существования вещей, напротив, пустота акцентирует внимание на реальном существовании самих вещей. Быть пустотным, значит быть реальным. Таким образом, утверждение являться реальным есть часть всеобщей цепи причинно-следственных явлений или отношений. Доказать существование вещей можно только в том случае, когда они вступают в причинно-следственные отношения друг с другом. Из этого суждения следует: если бы не происходили бы причинно-следственные отношения, то невозможно было бы доказать их присутствие, их реальное существование. «Пустота - всего лишь отсутствие истинного существования вещей» [2]. Познание феномена отрицания существования вещей бытия устраняет стереотип, возникающий из представлений о самосущности явлений, избавляя от омрачений. «Причина не есть возникновение через причину, а есть искусное [образование]. 
B. В. Дамеева, В. В. Хандархаева. Теория причинно-следственных связей в философии китайского буддизма

Если созерцать сущность через причинность, то постоянная [основа] возникновения не есть возникновение» [7].

Таким образом, если вещь не вступит в причинные отношения, то она не сможет осуществить действие на другие вещи, т. е. проявить существование себя. В аспекте взаимосвязи всех явлений и вещей, в процессе происходящего взаимовлияния одних связей на другие следует воспринимать эти вещи как взаимозависимые, или же «истинной таковостью». Существует сравнение понятия «истинная таковость» с «алмазной сетью Индры», похожей на гигантскую сеть над человечеством, в каждой точке которой расположен ограненный алмаз. В каждом алмазе мы можем увидеть отражение соседних алмазов, следовательно, каждый алмаз в сети - как голограммы, малая часть большой системы, воспроизводящей все целое. Каждый алмаз, отражая соседний алмаз через себя, следовательно, отражается в соседнем алмазе, отраженные друг другом все алмазы включают бесконечное взаимопроникновение во всей сети. Таким образом, единое включает в себя всеобщее, всеобщее - единое.

В учении Фа Цзана описываются мировоззренческие принципы школы хуаянь в понятиях десяти тайн:

1. Одновременное и взаимное возникновение (явления существуют без противоречий и не знают преград).

2. Явления не создают препятствий, сосуществуя друг с другом в пространственном отношении (разные и не похожие друг на друга вещи и явления могут оказаться одним большим и единым).

3. Сосуществование и различие единого и всеобщего (каждое явление обладает индивидуальностью, в то же время является частью большего всеобщего).

4. Взаимоопределяемость и самосущность всех явлений и вещей (не существует противоречий между действиями всех вещей, как в свою пользу, так и в пользу всеобщего).

5. Взаимодополняемость скрытого и явного (взаимозависимая необходимость событий).

6. Взаимосовместимость всех вещей (тождественность всех вещей и явлений как элементы одного всеобщего целого).

7. Сеть Индры (см. описание выше).

8. Непротиворечивость отдельных друг от друга вещей и явлений бытия (идей пустотности сущности вещей, которые не противоречат друг другу, достичь истины познания возможно).

9. Индивидуальное существование и всеобщая взаимозависимость вещей и явлений бытия (каждое явление присутствует во всех остальных явлениях бытия, имея свою индивидуальность).

10. Гармония, тождество и единство всех вещей и явлений природы бытия (концепция «дхармадату» (фачзе)).

Таким образом, в данной классификации мы видим, что прослеживается прочная взаимосвязь между причинно-следственными явлениями и предметами; явления и предметы, совершая определенные действия, получают соответствующие следствия из данных действий как причин. Следовательно, закономерность явлений и вещей бытия имеет глубокую взаимозависимость. Последователи учения школы хуаянь сосредоточивались на взаимозависимости сущего и ин- 
дивидуального сознания, а также индивидуального сознания и эмпирического мира. Они пришли к выводу о взаимозависимой связи между явлениями и предметами внутри эмпирического мира [6].

В школе хуаянь через принцип взаимодействия причинно-следственных связей пытались избежать субъективного идеализма, отрицая в то же время объективное существование материального мира, т. е. понятие сознания являлось определяющим в отношении материальных явлений и предметов бытия [8]. Следовательно, сознание выступает как ключевой первичный элемент, а предметы внешнего мира - как дополнительный. Фа Цзан описывал в своих трудах две стороны понятия сознания, где первая - единый разум, всеохватывающий разум; другая - двойственный разум, разум частного индивида, производящий мир [9]. При этом обе части взаимосвязаны друг с другом, не имеют возможности проявляться индивидуально друг от друга, следовательно, отдельно от разума частного индивида одновременно существует универсальный разум. В данном случае следует умозаключение, что сознание является и субстанцией, и субъектом.

Таким образом, в школе хуаянь причиной возникновения всех явлений и вещей считали «соединение порождающих и сопутствующих причин». Признавая явления за иллюзорный образ, для укрепления истинности природы вещей необходимо было устранить «кажимость» всех явлений и вещей, осознать природу пустотности явлений и предметов. Явления и вещи, согласно принципам учения школы хуаянь, несмотря на разную величину в пространственном промежутке, существуют благодаря взаимосвязи друг с другом.

Ключевым моментом в учениях школы хуаянь является утверждение идеи взаимопроникновения всего сущего и непротиворечивости существования явлений и предметов друг с другом, что стало ориентиром гармонизации и тождественности явлений и предметов в китайской философии буддизма. Таким образом, все сущее в эмпирическом мире взаимообусловлено, все взаимосвязано, одно зависит от всех, всё зависит от одного. Следовательно, все в природе бытия едино.

\section{Литература}

1. Великие мыслители Востока / пер. с англ. Н. Барановой, А. Блейз, С. Зинина, А. Коваля, Я. Никитина. Москва, 1998. С. 121-122. Текст: непосредственный

2. Геше Джампа Тинлей. Буддийская логика: комментарии к трактату Дхармакирти «Праманаварттика» / под редакцией И. С. Урбанаевой, А. Ю. Коноваловой. Улан-Удэ, 2011. С. 186-187. Текст: непосредственный.

3. История китайской философии: перевод с китайского / общая редакция и послесловие М. Л. Титаренко. Москва, 1989. С. 269-270. Текст: непосредственный.

4. Конрад Н. И. Запад и Восток. Москва, 1972. С. 111-112. Текст: непосредственный.

5. Мартынов А. С., Поршнева Е. Б. Учение и религия в Восточной Азии в период средневековья // Народы Азии и Африки. 1986. № 1. С. 79. Текст: непосредственный.

6. Янгутов Л. Е. Единство, тождество и гармония в философии китайского буддизма. Новосибирск, 1995. С. 137-138. Текст: непосредственный.

7. Янгутов Л. Е. Китайский буддизм: тексты, исследования, словарь. Улан-Удэ, 1998. С. 71-72. Текст: непосредственный.

8. Янгутов Л. Е. Философское учение школы хуаянь. URL: http://opentextnn. ru/man/jangutov-l-e-filosofskoe-uchenie-shkoly-huajan/ (дата обращения: 22.10.2021). Текст: электронный. 
В. В. Дамеева, В. В. Хандархаева. Теория причинно-следственных связей в философии китайского буддизма

9. Чжунго фоцзяо туцзи (“Китайский буддизм в иллюстрациях”). Сянган, 1956. Текст: непосредственный.

Статья поступила в редакциюю 22.10.2021; одобрена после рецензирования 30.10.2021; принята к публикации 15.11.2021.

\title{
THEORY OF CAUSE-AND-EFFECT RELATIONSHIPS IN THE PHILOSOPHY OF CHINESE BUDDHISM
}

\section{Vera V. Dasheeva}

Cand. Sci. (Philos.), A/Prof., Dorzhi Banzarov Buryat State University

24a Smolina St., Ulan-Ude 670000, Russia denisova.v@mail.ru

\author{
Viktoria V. Khandarkhaeva \\ Senior Lecturer, \\ Dorzhi Banzarov Buryat State University \\ 24a Smolina St., Ulan-Ude 670000, Russia \\ khandarkhaeva@yandex.ru
}

\begin{abstract}
Cause-and-effect relationships are an important aspect in understanding the philosophy of Chinese Buddhism. The article discusses the idea of the interaction of all phenomena and objects of the nature of existence, which do not have a real essence, but are a consequence of their emptiness having no negative quality. The philosophy of Chinese Buddhism reflects the harmony of the existence of the world with all objects, emphasizing the unity of all that exists with the nature of existence. This article considers the classifications of the worldview aspects of cause-and-effect relationships that contribute to overcoming the false picture of the world, the so-called "clouded mind", refuting the illusion of subject-object relations, achieving the true nature of existance and the harmony of all cause-and-effect relationships. The creation of the Huayan school led to the development of forms and methods in the theory of Chinese Buddhism. The author of this theory was the Chinese philosopher Fazang, who believed that the origin of all things and phenomena in the nature of existence is a consequence of cause-and-effect relationships.

Keywords: Buddhism, Chinese philosophy, Chinese Buddhism, cause-and-effect relationships, the Huayan school, Fazang, dharmadhatu, causality, everything that exists.
\end{abstract}

\section{For citation}

Dasheeva V. V., Khandarkhaeva V. V. Theory of Cause-and-Effect Relationships in the Philosophy of Chinese Buddhism. Bulletin of Buryat State University. Philosophy. 2021; 4: 26-31.

The article was submitted 22.10.2021; approved after reviewing 30.10.2021; accepted for publication 15.11.2021. 